\title{
The activity of glyceraldehyde 3-phosphate dehydrogenase in spermatozoa from different regions of the epididymis in laboratory rodents treated with a-chlorohydrin or 6-chloro-deoxyglucose
}

\author{
W. C. L. Ford and Anne Harrison \\ Department of Physiology \& Biochemistry, The University, Whiteknights, Reading RG6 2AJ, U.K.
}

\begin{abstract}
Summary. The activity of glyceraldehyde 3-phosphate dehydrogenase (GAPDH) (mUnits/106 spermatozoa: mean \pm s.e.m., $N=12$ ) in spermatozoa from the rat epididymis declined from $22 \cdot 0 \pm 1.4$ in the caput to $14 \cdot 1 \pm 1 \cdot 3$ in the corpus region but there was no further decrease in the cauda region. In hamsters $(\mathrm{N}=4)$, GAPDH activity in spermatozoa declined from $24 \cdot 8 \pm 2 \cdot 2$ in the caput to $15 \cdot 2 \pm 1 \cdot 2$ in the distal cauda epididymidis with the greatest decrease between the corpus and proximal cauda regions. In guinea-pigs $(\mathbf{N}=4)$ GAPDH activity in spermatozoa increased from 11.4 \pm 0.79 in the caput to $18.0 \pm 0.7$ in the corpus and cauda regions of the epididymis. The activity of GAPDH in spermatozoa therefore changes during maturation in a species dependent manner.

GAPDH in spermatozoa from the distal cauda epididymidis of rats given $\alpha$ chlorohydrin $(4,8$ or $25 \mathrm{mg} / \mathrm{kg} /$ day by mouth) or 6-chloro-6-deoxyglucose ( 24 or 96 $\mathrm{mg} / \mathrm{kg} /$ day by mouth) for 10 days was inhibited by $>80 \%$ but was only inhibited by $25-$ $45 \%$ in spermatozoa from the caput epididymidis. The enzyme was inhibited to an intermediate and dose-dependent extent in spermatozoa from the corpus region. A similar pattern of inhibition was seen in spermatozoa from hamsters given $\alpha$ chlorohydrin ( 50 or $100 \mathrm{mg} / \mathrm{kg} /$ day) for 10 days. $\alpha$-Chlorohydrin $(66 \mathrm{mg} / \mathrm{kg} /$ day s.c.) for 10 days inhibited GAPDH in spermatozoa from the caput or corpus epididymidis of the guinea-pig by $<20 \%$ but decreased GAPDH activity by almost $90 \%$ in the cauda region. In rats the greater effect of $\alpha$-chlorohydrin on spermatozoa from the cauda region of the epididymis occurred even after short periods of treatment or when the passage of spermatozoa through the duct was interrupted by a ligature around the corpus region, indicating that the effect is not simply a reflection of the length of time the spermatozoa have spent in the epididymis. It is concluded that either spermatozoa undergo a maturational change which increases their sensitivity to $\alpha$-chlorohydrin or that $\alpha$-chlorohydrin (or an active metabolite) is concentrated in the lumen of the cauda epididymidis.
\end{abstract}

\section{Introduction}

$\alpha$-Chlorohydrin (3-chloropropan-1,2-diol) has a reversible antifertility effect on male animals of many species including rams, boars, rats, hamsters and guinea-pigs but not mice and rabbits (see Jones, 1978; Lobl, 1980). 6-Chloro-6-deoxysugars have a similar effect on male rats and marmoset monkeys (see Ford, 1982). In some way these compounds produce a dramatic inhibition of glyceraldehyde 3-phosphate dehydrogenase (EC 1.2.1.12) in spermatozoa stored in the epididymis. 
This lesion prevents the spermatozoa metabolizing glucose through the glycolytic pathway and i: believed to be the basis of the contraceptive effect (see Ford, 1982). There is no comparable effec on glyceraldehyde 3-phosphate dehydrogenase in other tissues and even doses of 6-chloro-6 deoxyglucose 10 times higher than those required to produce a contraceptive effect did not inhibi the metabolism of glucose to lactate or $\mathrm{CO}_{2}$ in liver, kidney, brain or skeletal muscle from the ra (Ford \& Waites, 1981). This specificity of action implies that the epididymis concentrates the antifertility agent in its lumen so that spermatozoa are exposed to a higher concentration than art other cells or that spermatozoa are especially vulnerable to these compounds. There is somt evidence to favour each explanation.

The cauda epididymidis of the rat but not of the mouse accumulates radioactivity from [ $U$. $\left.{ }^{14} \mathrm{C}\right] \alpha$-chlorohydrin but not from $\left[{ }^{36} \mathrm{Cl}\right] \alpha$-chlorohydrin administered by intravenous injection or by oral gavage (Crabo \& Appelgren, 1972; E. M. Edwards \& G. M. H. Waites, persona communication). However, boar and rat spermatozoa, but not boar kidney tubules or rabbi spermatozoa, can convert $\alpha$-chlorohydrin to $\beta$-chlorolactaldehyde which may be the metabolite directly responsible for the inhibition of glyceraldehyde 3-phosphate dehydrogenase (Jones Stevenson, Hutton \& Dawson, 1981). To understand the basis of the specific action of $\alpha$. chlorohydrin or of the 6-chloro-6-deoxysugars on spermatozoa it would be useful to know where the drugs exert their effect in the epididymis. We have therefore measured the activity of glyceraldehyde 3-phosphate dehydrogenase in spermatozoa from different regions of the epididymis from rats, hamsters, guinea-pigs and mice treated with $\alpha$-chlorohydrin and from rats treated with 6-chloro-6-deoxyglucose.

Testicular spermatozoa are incapable of fertility or of progressive motility and acquire these attributes during their passage through the epididymis (see Mann \& Lutwak-Mann, 1981). This process of maturation is associated with changes in the pattern of energy metabolism, e.g. in boars and rams, spermatozoa from the cauda epididymidis oxidize glucose more rapidly than do spermatozoa from the rete testis or the caput epididymidis (see Dacheux \& Paquignon, 1980 Hammerstedt, 1981) and in guinea-pigs and in bulls there is a large increase in rate of conversion of glucose to lactate by mature compared to immature spermatozoa (Frenkel, Petersen \& Freund. 1973; see Voglmayr, 1975). It is unclear whether these changes are solely a result of modulation of enzyme activities by allosteric effectors or whether covalent modification of enzymes or changes in their concentration are involved. Glyceraldehyde 3-phosphate dehydrogenase probably catalyses the rate-limiting reaction in glycolysis in spermatozoa which have a high rate of flux through the pathway (Hoskins, Stephens \& Casillas, 1971; Hoskins, Munsterman \& Hall, 1975). The contro. animals in the experiments described here provide data on changes in the activity of this enzyme during sperm maturation.

\section{Materials and Methods}

\section{Animals and sources of material}

Mature male CD rats (300-500 g body weight) and CD-1 mice (25-30 g body weight) wert purchased from Charles River U.K. Ltd, Margate, Kent CT9 4LT, U.K. They were kept in $12 \mathrm{r}$ light/12 h dark and were given food (Diet 86 or 86A : Dixons, Ware SG12 9PZ, U.K.) and water ac libitum. Mature male golden hamsters $(85-110 \mathrm{~g}$ body weight) were obtained from Intersimian Ltd Abingdon OX14 4RY, U.K. They were kept in similar conditions to the rats but their diet wa: supplemented with nuts and seeds. Mature male guinea-pigs ( $760-900 \mathrm{~g}$ body weight) wer purchased from Lions Laboratories, Ringwood, Hants, U.K. They were fed Diet 18 (Dixons) at libitum supplemented with hay, and vitamin $\mathrm{C}$ (about $0.02 \%$ ) was added to the drinking water (RS) $\alpha$-chlorohydrin was purchased from Koch Light Ltd, Colnbrook SL3 0BZ, U.K. It wa: supplied as a faintly yellow liquid but became markedly discoloured after storage. Therefore it wa: redistilled under reduced pressure to yield a colourless liquid. 6-Chloro-6-deoxyglucose wa: 
supplied by Societe D'Industries Opothérapiques, 2 Rue Felicien-David, 78100 Ste Germain-en Laye, France, and conformed to standards of purity defined previously (Ford, Harrison \& Waites, 1981). Enzymes and co-enzymes were obtained from Sigma (London) Chemical Co. Ltd, Poole, Dorset BH17 7NH, U.K.

\section{Collection of spermatozoa and the assay of glyceraldehyde 3-phosphate dehydrogenase}

Rats were killed by cervical dislocation, mice and hamsters were killed with ether and guineapigs were anaesthetized with pentobarbitone sodium (Sagatal: May \& Baker, Dagenham, U.K.) $(1.0 \mathrm{ml} / \mathrm{kg}$ i.p.) and were killed by the injection of a further $0.3 \mathrm{ml}$ pentobarbitone into the femoral vein. The epididymides were carefully dissected free of fat and any blood adhering to the organ was removed as completely as possible by washing with $0.9 \%(\mathrm{w} / \mathrm{v})$ sodium chloride and mopping with tissues. The epididymides were then divided into regions (Text-fig. 1) and the portions were transferred to $10 \mathrm{ml}$ conical flasks which contained $2.0 \mathrm{ml}$ PBS buffer (Ford et al., 1981). Separate flasks were used for each animal except with the mouse tissue for which the epididymides of all the animals in a group were pooled. The portions of epididymis were chopped with scissors and the flasks were shaken for $30 \mathrm{~min}$ at $34^{\circ} \mathrm{C}$. The contents of the flasks were decanted into conical $15 \mathrm{ml}$ centrifuge tubes through a thin pad of surgical gauze which retained the epididymal fragments but allowed spermatozoa to pass through. The filter pad was washed with PBS buffer and the spermatozoa were centrifuged $\left(2000 \mathrm{~g}_{\mathrm{av}} 10 \mathrm{~min}, 4^{\circ} \mathrm{C}\right)$. The supernatant was discarded and the pellet was mixed with an approximately equal volume of $50 \%(\mathrm{v} / \mathrm{v})$ glycerol with a fine glass rod. The slurry was sucked into a number of short glass capillaries which were sealed with wax and placed in screw-capped plastic vials for storage under liquid nitrogen. The activity of glyceraldehyde 3phosphate dehydrogenase in hypotonic lysates of the spermatozoa was measured by following the reduction of glycerate 1,3-bisphosphate (Ford et al., 1981); 1 unit of enzyme reduced $1 \mu$ mol glycerate 1,3-bis-phosphate/min. The concentration of spermatozoa was calculated from the absorbance of a diluted suspension at $500 \mathrm{~nm}$ (see below).
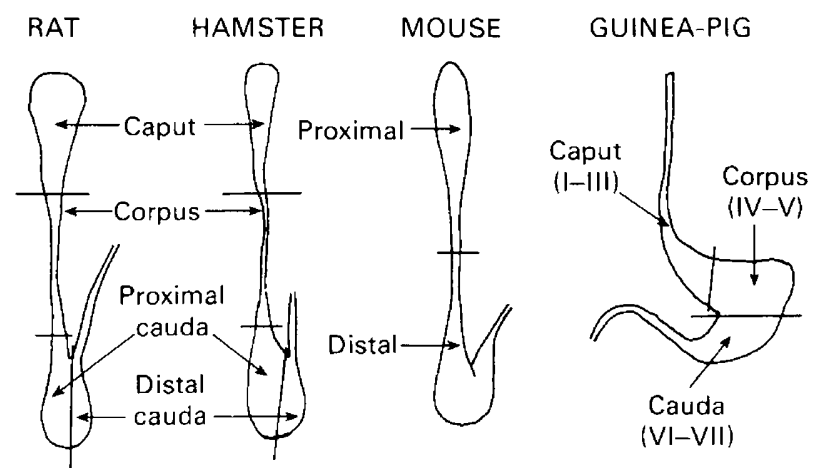

Text-fig. 1. The division of the epididymis into regions: Roman numerals after Hoffer \& Greenberg (1978).

Determination of the standard curves for deriving the concentration of spermatozoa from the absorbance of the suspension at $500 \mathrm{~nm}$

Spermatozoa were isolated from the different regions of the rat epididymis and from the entire epididymides of hamsters and guinea-pigs. Hypotonic lysates of the spermatozoa were prepared and a series of dilutions was made. In each case, the number of sperm heads was counted in a 
haemocytometer, the absorbance at $500 \mathrm{~nm}$ was measured in a Gilford 250 spectrophotometer and protein was determined by the method of Warburg \& Christian (1941) after the cells had been dissolved in $\mathrm{NaOH}$ (see Ford \& Harrison, 1981). The regressions of sperm concentration on absorbance at $500 \mathrm{~nm}$ and of protein concentration on sperm concentration were calculated assuming that the lines passed through the origin. In every case a highly significant straight line relationship was demonstrated (Table 1). The highest concentrations of spermatozoa measured $\left(10^{6} / \mathrm{ml}\right)$ were: rat, 49 ; hamster, 160 ; guinea-pig, 154 . These were greater than the concentrations used in the experiments. The significance of the differences between the regression coefficients were analysed by Analysis of Covariance and by the Simultaneous Test Procedure (see Sokal \& Rohlf, 1969). There were no significant differences between the various regions of the rat epididymis (Analysis of Covariance : sperm concentration against absorbance, $F=0.31$ for $3 \times 32$ d.f.; protein concentration against sperm concentration, $F=1.29$ for $3 \times 32$ d.f.) and the pooled value was used in all subsequent calculations. All differences between species were significant at the $P<0.01$ level. The results for mouse spermatozoa were calculated using the regression coefficient for rat spermatozoa.

Table 1. The regression coefficients (a) of sperm concentration $\left(10^{6} / \mathrm{ml}\right)$ on the absorbance $(A)$ of the suspension at $500 \mathrm{~nm}(1 \mathrm{~cm}$ cuvettes) and of protein concentration $(\mathrm{mg} / \mathrm{ml})$ on sperm concentration $\left(10^{6} / \mathrm{ml}\right)$

\begin{tabular}{|c|c|c|c|c|c|c|c|}
\hline & \multirow{2}{*}{$\begin{array}{l}\text { No. of } \\
\text { samples }\end{array}$} & \multicolumn{3}{|c|}{ Sperm conc. $\left(10^{6} / \mathrm{ml}\right)=\mathrm{a} \times A_{500}$} & \multicolumn{3}{|c|}{$\begin{array}{l}\text { Protein }(\mathrm{mg} / \mathrm{ml})=\mathrm{a} \times \text { sperm conc. } \\
\qquad\left(10^{6} / \mathrm{ml}\right)\end{array}$} \\
\hline & & $\mathrm{a}$ & s.e. & $t$ & a & s.e. & $t$ \\
\hline \multicolumn{8}{|l|}{ Rat } \\
\hline Caput & 16 & $48 \cdot 25$ & $2 \cdot 02$ & $23 \cdot 9$ & 0.218 & 0.016 & $13 \cdot 6$ \\
\hline Corpus & 8 & $48 \cdot 15$ & 1.99 & $24 \cdot 1$ & 0.255 & 0.035 & $7 \cdot 2$ \\
\hline Proximal cauda & 8 & 54.59 & $4 \cdot 19$ & 13.0 & 0.249 & $0 \cdot 030$ & $8 \cdot 3$ \\
\hline Distal cauda & 8 & $47 \cdot 31$ & $4 \cdot 22$ & $11 \cdot 2$ & 0.309 & 0.040 & $7 \cdot 8$ \\
\hline Pooled & 40 & $48 \cdot 83$ & $1 \cdot 27$ & $38 \cdot 5$ & $0 \cdot 236$ & 0.012 & $19 \cdot 4$ \\
\hline Hamster & 20 & $95 \cdot 07$ & $2 \cdot 73$ & $34 \cdot 5$ & 0.064 & 0.003 & $24 \cdot 3$ \\
\hline Guinea-pig & 16 & $174 \cdot 2$ & $2 \cdot 27$ & 76.9 & 0.039 & 0.0015 & $20 \cdot 8$ \\
\hline
\end{tabular}

\section{Treatment of animals with antifertility agents}

The antifertility agents were administered as aqueous solutions. They were given to rats, hamsters and mice by oral gavage and to guinea-pigs by subcutaneous injection.

Experiment 1. Groups of 4 rats were treated for 10 days: Group 1, no treatment (controls); Group 2, $8 \mathrm{mg} \alpha$-chlorohydrin $/ \mathrm{kg} /$ day; Group 3, $25 \mathrm{mg} \alpha$-chlorohydrin $/ \mathrm{kg} / \mathrm{day}$.

Experiment 2. Groups of 4 rats were treated for 10 days: Group 1, no treatment (controls); Group 2, $4 \mathrm{mg} \alpha$-chlorohydrin/kg/day; Group 3, $24 \mathrm{mg}$ 6-chloro-6-deoxyglucose/kg/day; Group 4, $96 \mathrm{mg}$ 6-chloro-6-deoxyglucose $/ \mathrm{kg} /$ day.

Experiment 3. Groups of 4 rats were treated with $8 \mathrm{mg} \alpha$-chlorohydrin $/ \mathrm{kg} / \mathrm{day}$ for different times: Group 1, no treatment (controls); Group 2, 1 day; Group 3, 2 days; Group 4, 4 days.

Experiment 4 . Rats were anaesthetized with pentobarbitone sodium $(0.9 \mathrm{ml} \mathrm{Sagatal} / \mathrm{kg}$ i.p. $)$ and the testes were exposed through a mid-line abdominal incision. A ligature was tied firmly around the epididymis in the centre of the caput region. Care was taken to pass the thread under the major blood vessels visible on the surface of the organ. The testes were restored to the scrotum and the incision was closed with sutures. The rats were divided into groups of 5. Groups 1 and 3 received no further treatment but Groups 2 and 4 were given $8 \mathrm{mg} \alpha$-chlorohydrin $/ \mathrm{kg} /$ day starting on the day after the operation. Groups 1 and 2 were killed 3 days after ligation and Groups 3 and 4 were killed 10 days after ligation. 
Experiment 5. Groups of 4 hamsters were treated for 10 days: Group $1,1 \mathrm{ml}$ water $/ \mathrm{kg} / \mathrm{day}$ (control); Group 2, $50 \mathrm{mg} \alpha$-chlorohydrin/kg/day; Group 3, $100 \mathrm{mg} \alpha$-chlorohydrin $/ \mathrm{kg} / \mathrm{day}$.

Experiment 6. Groups of 4 guinea-pigs were treated for 10 days: Group 1, $0.5 \mathrm{ml}$ water $/ \mathrm{kg} / \mathrm{day}$ (controls); Group 2, $66 \mathrm{mg} \alpha$-chlorohydrin $/ \mathrm{kg} /$ day.

Experiment 7. Groups of 8 mice were treated for 10 days: Group 1, no treatment (controls); Group 2, $44 \mathrm{mg} \alpha$-chlorohydrin/kg/day.

\section{Results}

Rats

In the control rats from Exps 1, 2 and 3 the activity of glyceraldehyde 3-phosphate dehydrogenase (mUnits $/ 10^{6}$ spermatozoa: mean \pm s.e.m. of 12 observations) declined from $22.0 \pm$ 1.4 in spermatozoa from the caput region to $14.1 \pm 1.25$ in spermatozoa from the corpus region $(P$ $<0.001)$. There were no significant differences between enzyme activity in spermatozoa from the corpus and from the proximal (13.8 \pm 0.96$)$ or the distal $(12.6 \pm 0.72)$ cauda region. The decline occurred in all the rats although its magnitude was variable. When the average activity of the enzyme in the spermatozoa from the 3 more distal regions was calculated for each animal, the values were between 38.6 and 86.4 (mean \pm s.e.m. $=64 \pm 4.9$ ) $\%$ of the activity in the caput spermatozoa. Although the pattern of enzyme activity in the different regions was the same in each experiment there were significant differences in the absolute values, e.g. glyceraldehyde 3phosphate dehydrogenase activity in spermatozoa from the caput region was $22 \cdot 2 \pm 1 \cdot 75,26 \cdot 7 \pm$ 1.35 and $17 \cdot 2 \pm 1 \cdot 24$ (mUnits/106 spermatozoa: $N=4$ ) in Exps 1, 2 and 3 respectively. In view of this the results with antifertility agents have been normalized so that the activity of glyceraldehyde 3-phosphate dehydrogenase in the controls became equal to 100 , and the standard errors shown have been increased in proportion.

The activity of glyceraldehyde 3-phosphate dehydrogenase in spermatozoa from all regions of the epididymis of rats treated with $\alpha$-chlorohydrin $(4,8$ or $25 \mathrm{mg} / \mathrm{kg} /$ day) for 10 days was significantly inhibited compared to its activity in spermatozoa from control rats (Text-fig. 2a). The inhibition was greatest in the cauda region and least in the caput region. The extent of inhibition was not dependent on the dose of $\alpha$-chlorohydrin except in the corpus region where a dose of 25 $\mathrm{mg} / \mathrm{kg} /$ day produced a $77 \%$ inhibition compared to 45 and $54 \%$ produced by 4 and $8 \mathrm{mg} / \mathrm{kg} / \mathrm{day}$ respectively. The difference between the effect of 8 and $25 \mathrm{mg} / \mathrm{kg} /$ day was statistically significant $(P<0.001, t$ test $)$. The largest increment in inhibition occurred between the corpus and proximal cauda regions for the 2 lower doses and between the caput and the corpus region for the highest dose.

A very similar pattern of inhibition was observed after treatment with 6-chloro-6-deoxyglucose (24 or $96 \mathrm{mg} / \mathrm{kg} /$ day) except that the lower dose inhibited glyceraldehyde 3-phosphate dehydrogenase in spermatozoa from the proximal cauda region to a lesser extent than did any of the doses of $\alpha$-chlorohydrin (Text-fig. $2 b$ ).

After rats had been treated with $\alpha$-chlorohydrin $(8 \mathrm{mg} / \mathrm{kg} /$ day) for 1 day, the activity of glyceraldehyde 3-phosphate dehydrogenase in spermatozoa from the caput, proximal cauda and distal cauda regions appeared to be inhibited by about $25 \%$ but this was statistically significant only in the distal cauda region. After 2 days treatment the activity of the enzyme was inhibited to a statistically significant extent in the corpus region and to a more marked extent in the distal cauda region. After 4 days there was significant inhibition in all regions. The inhibition was greatest in the distal cauda region and least in the caput region with a gradation through the intervening regions (Text-fig. 2c).

In rats in which a ligature had been placed around the middle of the corpus region, treatment with $\alpha$-chlorohydrin ( $8 \mathrm{mg} / \mathrm{kg} / \mathrm{day}$ ) for 2 days produced a significant inhibition of glyceraldehyde 3 phosphate dehydrogenase activity in spermatozoa from the corpus region proximal to the ligature 


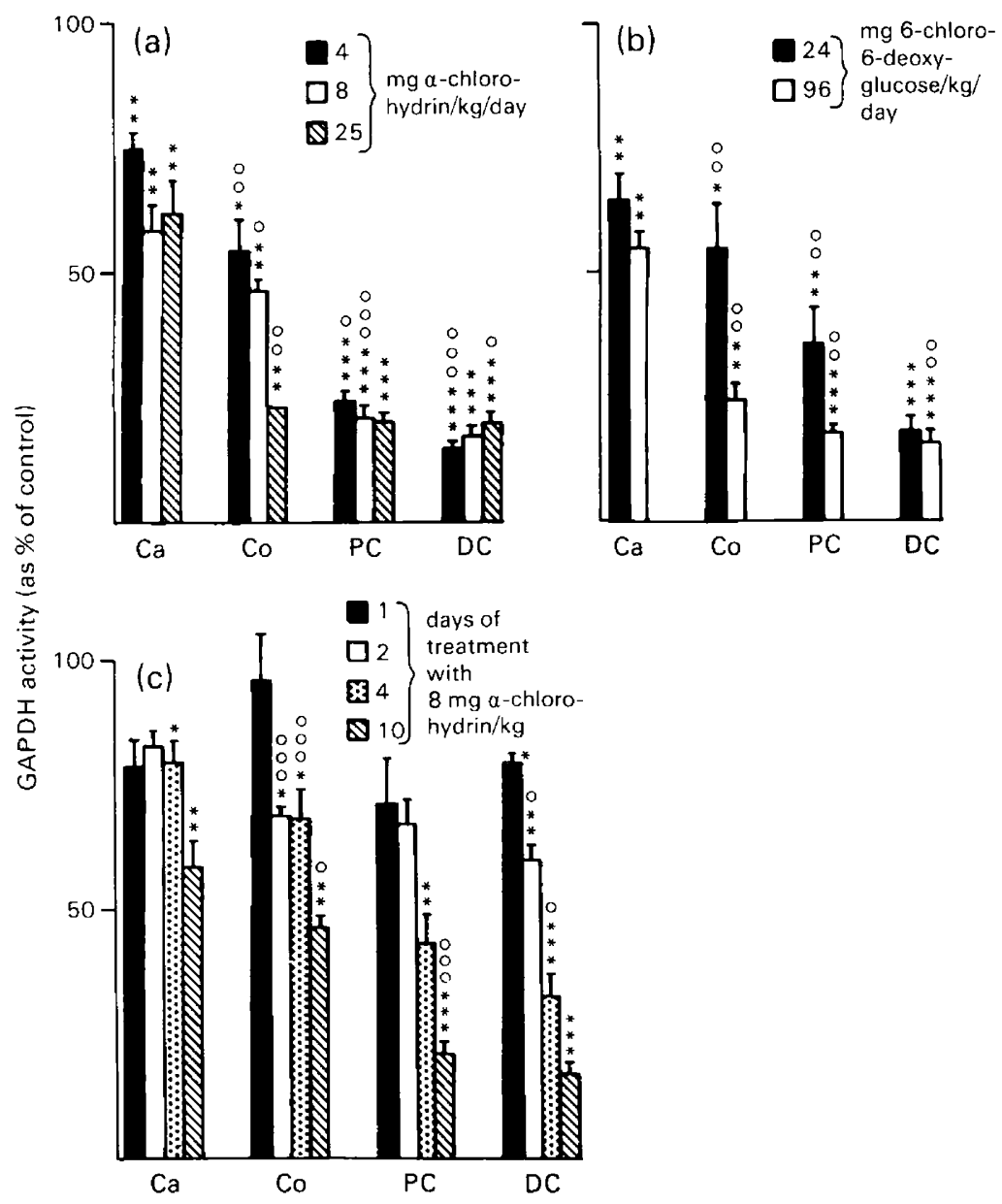

Text-fig. 2. The effect of treating male rats with antifertility agents on the activity of glyceraldehyde 3-phosphate dehydrogenase (GAPDH) in spermatozoa from different regions of the epididymis: (a) $\alpha$-chlorohydrin for 10 days; (b) 6-chloro-6-deoxyglucose for 10 days; (c) 8 $\mathrm{mg} \alpha$-chlorohydrin $/ \mathrm{kg}$. $\mathrm{Ca}=$ caput $; \mathrm{Co}=$ corpus; $\mathrm{PC}=$ proximal cauda $; \mathrm{DC}=$ distal cauda. Values are mean \pm s.e.m. for 4 rats with the control for each region normalized to 100 . Significantly different from corresponding control $\left(t\right.$ test): ${ }^{*} P \leq 0.05,{ }^{* *} P \leq 0.01,{ }^{* * *} P \leq$ $0 \cdot 001$. Significantly different from preceding region given the same treatment (paired $t$ test): ${ }^{\circ} P$ $\leq 0.05,{ }^{\circ \circ} P \leq 0.01,{ }^{\text {ooo } P} \leq 0.001$.

and in spermatozoa from the cauda epididymidis. The inhibition was most pronounced in spermatozoa from the proximal corpus region. There was no effect on spermatozoa from the caput region (Table 2). When the corpus epididymidis had been ligated for 10 days the corpus epididymidis proximal to the ligature was distended with spermatozoa whereas distal to the ligature no spermatozoa were present in the duct until the distal cauda region. In these rats treatment with $\alpha$-chlorohydrin ( $8 \mathrm{mg} / \mathrm{kg} /$ day) for 9 days produced significant inhibition of glyceraldehyde 3-phosphate dehydrogenase in spermatozoa from the proximal corpus and from the distal cauda region. Inhibition was more pronounced in the latter case (Table 2).

\section{Hamsters}

The activity of glyceraldehyde 3-phosphate dehydrogenase in spermatozoa from the hamster epididymis declined significantly in passing from the caput epididymidis to the distal cauda region 
Table 2. The effect of treatment with $8 \mathrm{mg} \alpha$-chlorohydrin $/ \mathrm{kg} /$ day on the activity of glyceraldehyde 3 phosphate dehydrogenase (mUnits $/ 10^{6}$ spermatozoa) in spermatozoa from the epididymides of rats with a ligature placed around the mid-corpus epididymidis

\begin{tabular}{lccccc}
\hline \multirow{2}{*}{ Treatment } & \multicolumn{4}{c}{ Region of epididymis } \\
\cline { 3 - 6 } & Days ligation & Caput & Proximal corpus & Proximal cauda & Distal cauda \\
\hline \multirow{2}{*}{ Control } & $3(\mathrm{~N}=4)$ & $15.5 \pm 1.45$ & $16.3 \pm 1.63$ & $12.9 \pm 0.52$ & $13.4 \pm 1.58$ \\
& 10 & $15.9 \pm 1.08$ & $12.4 \pm 0.70$ & - & $10.3 \pm 1.85$ \\
\multirow{2}{*}{$\alpha$-chlorohydrin } & 3 & $16.5 \pm 1.65$ & $8.8 \pm 0.60^{* *}$ & $9.4 \pm 1 \cdot 12^{*}$ & $9 \cdot 1 \pm 0.88^{*}$ \\
& 10 & $12.2 \pm 1.18(3)$ & $5 \cdot 7 \pm 1 \cdot 78(3)^{* *}$ & - & $2 \cdot 7 \pm 0.54^{* * *}$ \\
\hline
\end{tabular}

Values are mean \pm s.e.m. for 5 rats/group, except as indicated in parentheses. Significantly different from control ( $t$ test): ${ }^{*} P<0.05,{ }^{* *} P<0.01,{ }^{* * *} P<0.001$.

Table 3. The activity of glyceraldehyde 3-phosphate dehydrogenase (mUnits/10 $10^{6}$ spermatozoa) in spermatozoa from different regions of the epididymis from hamsters given 10 daily doses of $\alpha$ chlorohydrin

\begin{tabular}{|c|c|c|c|c|}
\hline \multirow[b]{2}{*}{ Dose $(\mathrm{mg} / \mathrm{kg} /$ day) } & \multicolumn{4}{|c|}{ Region of epididymis } \\
\hline & Caput & Corpus & Proximal cauda & Distal cauda \\
\hline 0 (Control) & $\begin{array}{c}24.8 \\
+2.17\end{array}$ & $26 \cdot 1 \S$ & $\begin{array}{l}18 \cdot 5 \\
+2 \cdot 71\end{array}$ & $\begin{array}{r}15.2^{*} \\
+1.21\end{array}$ \\
\hline 50 & $\overline{11} \cdot 0 \dagger+$ & $13 \cdot 2$ & $11 \cdot 0$ & $5 \cdot 7+\dagger$ \\
\hline & \pm 1.94 & \pm 2.92 & $\pm 2 \cdot 13$ & $\pm 1 \cdot 30 \ddagger$ \\
\hline 100 & $14 \cdot 0+\dagger$ & $11 \cdot 6$ & $9 \cdot 0 \div * *$ & $2 \cdot 5+t \dagger$ \\
\hline & $\pm 0 \cdot 30(3)$ & $\pm 1 \cdot 42$ & $\pm 2 \cdot 48$ & $\pm 0 \cdot 76 \ddagger^{* *}$ \\
\hline
\end{tabular}

Values are mean \pm s.e.m. for 4 animals, except as indicated by $\S$ when material from all the animals was pooled.

Significantly different from caput region at same dose ${ }^{*} P<0.05,{ }^{* *} P<0.01$; from proximal cauda region at same dose $\ddagger P<0.05$ (paired $t$ test); from corresponding control region $\dagger P<0.05, \uparrow \dagger P<0.01$, $\uparrow \dagger \dagger P<0.001$ ( $t$ test).

(Table 3). The greatest decline in enzyme activity occurred between the corpus and proximal cauda regions but very few spermatozoa were recovered from the corpus region and the material used in the assay had to be pooled from all the animals in the group. $\alpha$-Chlorohydrin inhibited the enzyme activity in spermatozoa from every region of the epididymis. The extent of inhibition was about $50 \%$ in the caput epididymidis and about $80 \%$ in the distal cauda epididymidis. There was no significant difference between spermatozoa from rats treated with $50 \mathrm{mg} \alpha$-chlorohydrin $/ \mathrm{kg} / \mathrm{day}$ and from those given $100 \mathrm{mg} / \mathrm{kg} /$ day (Table 3 ).

\section{Guinea-pigs}

The activity of glyceraldehyde 3-phosphate dehydrogenase (mUnits $/ 10^{6}$ spermatozoa, $\mathrm{N}=4$ ) in spermatozoa increased from 11.6 \pm 0.79 in the caput epididymidis to $18.0 \pm 0.77$ and $18.2 \pm$ 0.68 in the corpus and cauda regions respectively $(P<0.001)$. When the animals were treated with $\alpha$-chlorohydrin (66 mg/kg/day for 10 days) the activity of the enzyme was inhibited to a small but statistically significant extent in spermatozoa from the corpus region $(15.1 \pm 0.47, P<0.05)$ but was dramatically decreased in spermatozoa from the cauda region $(2.2 \pm 0.40, P<0.001)$.

\section{Mice}

The activity of glyceraldehyde 3-phosphate dehydrogenase (mUnits $/ 10^{6}$ spermatozoa, mean \pm s.e.m. of 4 assays) in mouse spermatozoa from the distal part of the epididymis $(37.8 \pm 0.97)$ was 
slightly greater than in spermatozoa from the proximal part $(31 \cdot 1 \pm 0.62, P<0.01)$. The enzyme was significantly inhibited in spermatozoa from mice given $\alpha$-chlorohydrin $(44 \mathrm{mg} / \mathrm{kg} /$ day for 10 days) and the inhibition was greater in the distal $(13.6 \pm 1 \cdot 09, P<0.001)$ than in the proximal $(22.6$ $\pm 0.87, P<0.001)$ part of the duct.

\section{Discussion}

The data described above are open to criticism because the spermatozoa were prepared by mincing the epididymis and could be contaminated with blood cells and with epididymal debris. The latter source of error was not significant in ram spermatozoa obtained by mincing the epididymis after blood had been removed by perfusing the organ with saline (Amann, Hay \& Hammerstedt, 1982). Our preparations were contaminated with erythrocytes and some samples from the caput and the corpus region had a pink discoloration. However, we do not believe that this had a serious effect on the results. (1) There was no correlation between the activity of glyceraldehyde 3-phosphate dehydrogenase in spermatozoa from a given region and the degree of discoloration of the sample. (2) In rats and in hamsters the activity of the enzyme was greater in spermatozoa from the caput than from the cauda epididymidis but the reverse was true in guinea-pigs although greater contamination was present in the caput samples of all species. (3) Glyceraldehyde 3-phosphate dehydrogenase from most tissues is a readily soluble enzyme but it remains tightly bound to the insoluble fraction of spermatozoa (Storey \& Kayne, 1975; W. C. L. Ford \& A. Harrison, unpublished observations). In our lysates of rat spermatozoa only $2 \cdot 7-3 \cdot 1 \%$ of the glyceraldehyde 3 phosphate dehydrogenase was present in the $100000 \mathrm{~g}$ supernatant from caput spermatozoa and $1.7-1.8 \%$ from cauda spermatozoa (duplicate observations). Therefore an overwhelming fraction of the enzyme activity was insoluble and there was little difference between preparations from the caput and from the cauda regions. (4) The concentration of protein per $10^{6}$ spermatozoa did not change significantly between the different regions of the rat epididymis (Table 1). (5) The extent of contamination was similar in preparations from animals treated with $\alpha$-chlorohydrin or 6-chloro-6deoxyglucose and from controls.

These experiments demonstrate that the activity of glyceraldehyde 3-phosphate dehydrogenase in spermatozoa changes during maturation. The assays were performed at high dilution and the specific activity (Units/mg protein) was independent of the concentration of sperm suspension in the assay system. Therefore the changes observed are unlikely to be due to the influence of allosteric effectors. However, they could be caused by synthesis or by degradation of the enzyme, by changes in the way it is bound to cellular organelles or by covalent modification of its structure. It is unlikely that the enzyme protein can be transferred across the plasma membrane of the spermatozoa so the change in activity must be produced by mechanisms which exist in the sperm cell although these could be triggered by external stimuli.

The increase in the activity of glyceraldehyde 3-phosphate dehydrogenase in guinea-pig spermatozoa occurred between the caput and the corpus epididymidis whereas the maximum increment in glycolytic flux occurs more distally (Frenkel et al., 1973). The increase in enzyme activity took place in the same region as morphological maturation of the sperm head (Fawcett $\&$ Hollenberg, 1963) and occurs at about the same time or just before the spermatozoa become fertile and progressively motile (Shilon, Paz, Hommonai \& Schoenbaum, 1978; Williamson, Shepherd \& Martan, 1980). Therefore it is probable that the increase in glyceraldehyde 3-phosphate dehydrogenase activity forms part of a pattern of maturational changes which prepare the spermatozoa for the demands of fertility. However, the enzyme activity reported here is greatly in excess of the maximum glycolytic flux (Frenkel et al., 1973).

It is more difficult to rationalize the decrease in the activity of the enzyme observed during the maturation of spermatozoa in rats and in hamsters but mature spermatozoa from these species rely on mitochondrial oxidation of substrates and do not accumulate lactate when incubated with 
glucose under aerobic conditions (Ford, Harrison, Takkar \& Waites, 1979). The flux through the glycolytic pathway therefore remains low. No data are available on the metabolism of immature spermatozoa from these rodents and the metabolic changes which accompany the decrease in enzyme concentration remain a matter for speculation. In hamsters the largest fall in glyceraldehyde 3-phosphate dehydrogenase activity in the spermatozoa occurred in a slightly more distal region of the epididymis than in rats. The maturation of hamster spermatozoa also occurs more distally than that of rat spermatozoa (see Dacheux \& Paquignon, 1980). In both species the decline in enzyme activity occurred in the region of the epididymis where the spermatozoa become capable of progressive motility (Hinton, Dott \& Setchell, 1979; Kann \& Serres, 1980) and where the concentration of carnitine in the lumen of the duct increases sharply (Hinton, Snoswell \& Setchell, 1979). These changes precede the acquisition of fertility by the spermatozoa.

Glyceraldehyde 3-phosphate dehydrogenase in mouse spermatozoa was markedly inhibited by $\alpha$-chlorohydrin treatment and the effect was greater in the distal half of the epididymis. This was surprising because $\alpha$-chlorohydrin does not have an antifertility effect in mice (see Jones, 1978). However, a dose of $44 \mathrm{mg} / \mathrm{kg} /$ day is the largest that can be given without producing widespread neurotoxicity. It was sufficient to impair the fertilizing ability of mouse spermatozoa (Samojlik \& Chang, 1970; Tsunoda \& Chang, 1976; Ford \& Waites, 1982).

$\alpha$-Chlorohydrin or 6-chloro-6-deoxyglucose has a greater effect on spermatozoa in the cauda epididymidis than on those in more proximal regions of the duct. These regional differences are most clear-cut in the guinea-pig. The increased effect in the cauda epididymidis was not due solely to a longer period of exposure to the drug because (1) the extent of inhibition was greatest in the cauda even after short periods of treatment (Text-fig. 2c), and (2) spermatozoa in the cauda were still inhibited when the passage of spermatozoa from more proximal regions of the duct was prevented by ligation (Text-fig. 4). The observations could be explained in 2 ways: either $\alpha$ chlorohydrin or an active metabolite was present in a higher concentration in the lumen of the cauda epididymidis than elsewhere in the duct or spermatozoa undergo a maturational change which increases their sensitivity to the drug. A longer period of pre-incubation and a higher concentration of $\alpha$-chlorohydrin was needed to inhibit the metabolism of glucose or of glycerol by ram testicular spermatozoa than to have the same effect on spermatozoa from the cauda epididymidis (Edwards, Dacheux \& Waites, 1976). The effect of $\alpha$-chlorohydrin on rat spermatozoa in the corpus epididymidis was increased when they were trapped there for 10 days by ligation of the duct (Table 2). Spermatozoa can mature in more proximal regions of the duct after this treatment (see Bedford, 1975). Therefore the present evidence supports the latter hypothesis. In either case $\alpha$-chlorohydrin could be an important tool to study epididymal physiology and sperm maturation and may offer some insight into how safe male contraceptives could be developed.

We are grateful for helpful discussions with Professor G. M. H. Waites. Financial support was provided by the M.R.C. (Grant No. G7909550 SB).

\section{References}

Amann, R.P., Hay, S.R. \& Hammerstedt, R.H. (1982) Yield, characteristics, motility and cAMP content of sperm isolated from seven regions of ram epididymis. Biol. Reprod. 27, 723-733.

Bedford, J.M. (1975) Maturation, transport and fate of spermatozoa in the epididymis. In Handbook of Physiology, Section 7, Endocrinology, Vol. 5, pp. 303317. Eds D. W. Hamilton \& R. O. Greep. Am. Physiol. Soc., Washington, D.C.

Crabo, B.G. \& Appelgren, L.-E. (1972) Distribution of $\left[{ }^{14} \mathrm{C}\right] \alpha$-chlorohydrin in mice and rats. J. Reprod. Fert. 30, $161-163$.
Dacheux, J.-L. \& Paquignon, M. (1980) Relations between the fertilizing ability, motility and metabolism of epididymal spermatozoa. Repr. Nutr. Develop. 20, $1085-1099$.

Edwards, E.M., Dacheux, J.-L. \& Waites, G.M.H. (1976) Effects of $x$-chlorohydrin on the metabolism of testicular and epididymal spermatozoa of rams. $J$. Reprod. Fert. 48, 265-270.

Fawcett, D.W. \& Hollenberg, R.D. (1963) Changes in the acrosome of guinea pig spermatozoa during passage through the epididymis. Z. Zellforsch. mikrosk. Anat. 60, $276-292$. 
Ford, W.C.L. (1982) The mode of action of 6-chloro-6deoxysugars as antifertility agents in the male. In Progress Towards a Male Contraceptice, pp. 159-184. Eds M. Sandler \& S. Jeffcoate. Wiley, London.

Ford, W.C.L. \& Harrison, A. (1981) The role of oxidative phosphorylation in the generation of ATP in human spermatozoa. J. Reprod. Fert. 63, 271-278.

Ford, W.C.L. \& Waites, G.M.H. (1981) The effect of high doses of 6-chloro-6-deoxyglucose on the rat. Contraception 24, 577-588.

Ford, W.C.L. \& Waites, G.M.H. (1982) Activities of 6chloro-6-deoxysugars and (S) $\alpha$-chlorohydrin in producing spermatocoeles in rats and paralysis in mice and in inhibiting glucose metabolism in bull spermatozoa in vitro. J. Reprod. Fert. 65, 177-183.

Ford, W.C.L., Harrison, A., Takkar, G.L. \& Waites, G.M.H. (1979) Inhibition of glucose catabolism in rat, hamster, rhesus monkey and human spermatozoa by $\alpha$-chlorohydrin. Int. J. Androl. 2, 275-288.

Ford, W.C.L., Harrison, A. \& Waites, G.M.H. (1981) Effects of 6-chloro-6-deoxysugars on glucose oxidation in rat spermatozoa. J. Reprod. Fert. 63, 67-73.

Frenkel, G. Peterson, R.N. \& Freund, M. (1973) Changes in the metabolism of guinea pig sperm from different segments of the epididymis. Proc. Soc. exp. Biol. Med. 143, 1231-1236.

Hammerstedt, R.H. (1981) Monitoring the metabolic rate of germ cells and sperm. In Reproductive Processes and Contraception, pp. 353-391. Ed. K. W. McKerns. Plenum, New York.

Hinton, B.T., Dott, H.M. \& Setchell, B.P. (1979) Measurement of the motility of rat spermatozoa collected by micropuncture from the testis and from different regions along the epididymis. J. Reprod. Fert. 55, 167-172.

Hinton, B.T., Snoswell, A.M. \& Setchell, B.P. (1979) The concentration of carnitine in the luminal fluid of the testis and epididymis of the rat and some other mammals. J. Reprod. Fert. 56, 105-111.

Hoffer, A.P. \& Greenberg, J. (1978) The structure of the epididymis, efferent ductules and ductus deferens of the guinea pig. Anat. Rec. 190, 659-678.

Hoskins, D.D., Stephens, D.T. \& Casillas, E.R. (1971) Enzymic control of fructolysis in primate spermatozoa. Biochim. Biophys. Acta 237, 227-238.

Hoskins, D.D., Munsterman, D. \& Hall, M.L. (1975) The control of bovine sperm glycolysis during epididymal transit. Biol. Reprod. 12, 566-572.
Jones, A.R. (1978) The antifertility actions of $\alpha$ chlorohydrin in the male. Life Sci. 23, 1625-1646.

Jones, A.R., Stevenson, D., Hutton, P. \& Dawson, A.G. $(1 ; 81)$ The antifertility action of $\alpha$-chlorohydrin: metabolism by rat and boar sperm. Experientia 37 , 340-341.

Kann, M.-L. \& Serres, C. (1980) Development and initiation of sperm motility in the hamster epididymis. Reprod. Nutr. Develop. 20, 1739-1749.

Lobl, T.J. (1980) $\alpha$-Chlorohydrin: review of a model post-testicular antifertility agent. In Regulation of Male Fertility, pp. 109-122. Eds G. R. Cunningham, W. B. Schill \& E. S. E. Hafez. Martinus Nijhof, The Hague.

Mann, Th. \& Lutwak-Mann, C. (1981) Male Reproductive Function and Semen. Springer-Verlag, Berlin.

Samojlik, E. \& Chang, M.C. (1970) Antifertility activity of 3-chloro-1,2-propanediol (U-5897) on male rats. Biol. Reprod. 2, 299-304.

Shilon, M., Paz, G., Hommonai, Z.T. \& Schoenbaum, M. (1978) The effect of caffeine on guinea pig epididymal spermatozoa: motility and fertilizing capacity. Int. J. Androl. 1, 416-423.

Sokal, R.R. \& Rohlf, F.J. (1969) Biometry: The Principles and Practice of Statistics in Biological Research. W. H. Freeman \& Co., San Francisco.

Storey, B.T. \& Kayne, F.J. (1975) Energy metabolism of spermatozoa. V. The Embden-Meyerhof pathway of glycolysis. Activities of pathway enzymes in hypotonically treated rabbit epididymal spermatozoa. Fert. Steril. 26, 1257-1265.

Tsunoda, Y. \& Chang, M.C. (1976) Fertilizing ability in vito and in vitro of spermatozoa of rats and mice treated with $\alpha$-chlorohydrin. J. Reprod. Fert. 46, 401406.

Voglmayr, J.K. (1975) Metabolic changes in sperm during epididymal transit. In Handbook of Physiology, Section 7, Endocrinology, Vol. V, pp. 437-451. Eds D. W. Hamilton \& R. O. Greep. Am. Physiol. Soc., Washington, D.C.

Warburg, O. \& Christian, W. (1941) Isolation and crystallization of enolase from a yeast ferment. Biochem. Z. 310, 384-421.

Williamson, B.L., Shepherd, B.A. \& Martan, J. (1980) Fertility of spermatozoa from the excurrent ducts of the guinea-pig. J. Reprod. Fert. 59, 515-517.

Received 13 January 1983 